\title{
Short-term effects of green tea chronotherapy on the metabolic homeostasis of mice on different diets
}

R.P. Amorim ${ }^{1}$, I.P. Daher ${ }^{1}$, F.P.D. Arcangelo ${ }^{2}$, M.F. Bellini ${ }^{1,2}$, W.A. Orcini ${ }^{2}$, G.R. Sarria ${ }^{1}$ and R.L. Peruquetti ${ }^{1,2}$

${ }^{1}$ Centro de Ciências da Saúde, Universidade do Sagrado Coração, Bauru, SP, Brasil

${ }^{2}$ Laboratório de Biologia Molecular e Citogenética,

Universidade do Sagrado Coração, Bauru, SP, Brasil

Corresponding author: R.L. Peruquetti

E-mail: rita.peruquetti@usc.br

Genet. Mol. Res. 16 (2): gmr16029605

Received January 12, 2017

Accepted March 30, 2017

Published May 10, 2017

DOI http://dx.doi.org/10.4238/gmr16029605

Copyright $(2017$ The Authors. This is an open-access article distributed under the terms of the Creative Commons Attribution ShareAlike (CC BY-SA) 4.0 License.

\begin{abstract}
Biological rhythms can be defined as changes in physiological or behavioral variables that repeat at certain time intervals. Rhythms that last approximately $24 \mathrm{~h}$ are referred to as circadian rhythms. Modern lifestyles have drastically affected human habits, as well as the population's eating habits. These changes have generated an epidemic of metabolic syndromes, such as obesity and diabetes. In an attempt to combat obesity, populations have attempted to use many different herbal remedies and plant-based drugs, the most common of which is Camellia sinensis, or green tea. Most of the studies on the effects of $C$. sinensis on maintaining body weight have reported the involvement of this substance in lipid oxidation. The objective of this study was to evaluate how the administration of $C$. sinensis at different times of day influenced changes in body weight, blood glucose levels, and food intake of mice kept under different diet
\end{abstract}

Genetics and Molecular Research 16 (2): gmr16029605 
conditions. The structural organization of abdominal adipose tissue was also evaluated, as were certain aspects of lipid metabolism and overall synthetic activity in the liver, adipose tissue, and ovaries. The results obtained suggest that the intake of green tea in the light phase of the day stimulates weight loss, regardless of the diet ingested. Neither glucose levels nor the structural organization of adipose tissue was found to be altered in any of the experimental groups. Neither diet nor the time at which the green tea was administered was found to have any effects on the amount of food the mice consumed. The time at which green tea was consumed and the type of diet both influenced LXRa $\beta$ nuclear receptor expression, as well as the expression of fibrillarin in the liver and ovaries, although this influence was tissue specific.

Key words: Green tea; Circadian rhythms; LXRa $\beta$; Fibrillarin; Metabolism

\section{INTRODUCTION}

Overweight is a condition in which individuals accumulate abnormal quantities of fat. It has been postulated that this condition is the main cause of the development of metabolic syndromes, such as obesity, type 2 diabetes, and cardiovascular diseases (Al-Daghri et al., 2015). It has been shown that energy homeostasis, which is classically defined as the balance of all the ingested and spent energy, is clearly unbalanced in overweight individuals (Staels, 2006). According to the World Health Organization (WHO), more than 1.4 billion adults are overweight. The most recent international data available is a WHO prediction that 2.3 billion adults would be overweight by 2015 (WHO, 2008). Due to the ever-growing obesity pandemic, the anti-obesity effects of many natural products are being increasingly investigated through the use of cell-based, animal, and human studies (Wolfram et al., 2006).

Green tea (Camellia sinensis) is an herbal product commonly used to control body weight, and it is the most popular natural weight loss remedy among many populations (Wolfram et al., 2006). Green tea is also known for reducing the risk of cardiovascular events and stroke by enhancing endothelial-dependent vasodilation (Ras et al., 2011) and for improving residual albuminuria among patients with diabetic nephropathy (Borges et al., 2016). Aqueous green tea preparations are known to have large amounts of polyphenol catechins, as well as caffeine (Kovacs et al., 2004). Among all the green tea polyphenols, epigallocatechin-3-gallate (EGCG) has been identified as the main agent behind the health benefits provided by green tea (Khan and Mukhtar, 2007). Caffeine acts by inhibiting phosphodiesterase, which generates an inhibitory effect in the control of the extended release of noradrenaline in lipid metabolism. Likewise, catechins are also known to have some inhibitory activities against catechol-Omethyl transferase, an enzyme that degrades noradrenaline. It is likely that the combination of caffeine and catechins is more effective in controlling and combating obesity than either of the components alone (Khan and Mukhtar, 2007). In summary, the main mechanisms of action exhibited by green tea in body weight maintenance involve: 1) increasing thermogenesis and fat oxidation (Diepvens et al., 2006), 2) decreasing total cholesterol, LDL, insulin, and plasma triglyceride concentrations (Chanadiri et al., 2005; Wu et al., 2012), 3) increasing energy expenditure while decreasing the respiratory quotient (Dulloo et al., 1999), and 4) decreasing

Genetics and Molecular Research 16 (2): gmr16029605 
adipogenesis while increasing rates of apoptosis in mature adipocytes (Lin et al., 2005).

Chronotherapy is a technique in which drug delivery is limited to certain times of the day when the effectiveness of its administration is higher and fewer side effects are therefore produced (Lis et al., 2003). The principle of this technique involves coordination between the time of drug administration, the therapeutic effect of the drug, the body's biological rhythms (i.e., circadian cycles), and the needs of the target organism (White et al., 2001).

During the evolutionary process, eukaryotic organisms have developed molecular mechanisms that allow for synchronization of their physiology to the 24-h daily cycle, and the processes that follow this fluctuation pattern are called circadian cycles (Froy, 2010). The synchronization of these events allows organisms to adapt and to anticipate their responses to external stimuli, such as the presence or absence of light in the environment, as well as the availability and/or quality of food (King and Takahashi, 2000). In mammals, the central biological clock is located in the suprachiasmatic nucleus of the hypothalamus (Mota, 2010). The suprachiasmatic nucleus and its efferent targets in the hypothalamus bring together light and feeding signals to entrain both behavioral rhythms and clock cells located in peripheral tissues such as the liver, adipose tissue, and muscle (Gooley, 2016).

The role that both central and peripheral molecular circadian machinery perform in the control of overall metabolic activity has been studied extensively in recent years (Marcheva et al., 2009; Bellet and Sassone-Corsi, 2010; Froy, 2010; Maury et al., 2010; Asher and Schibler, 2011; Orozco-Solis et al., 2016). Anticipatory mechanisms before food ingestion, such as an increase in body temperature and duodenal secretion, as well as the final processing of the metabolites, are all controlled by circadian machinery (Stephan, 2002). Changes in the availability of food (i.e., food restriction) (Stokkan et al., 2001; Hara et al., 2001), as well as changes in food composition (i.e., high caloric intake) (Kohsaka et al., 2007) appear to alter both peripheral and central circadian expression of some of the proteins responsible for metabolic control.

Reproductive physiology is another event that is deeply influenced by biological rhythms (Boden and Kennaway, 2006). Evidence indicates that mammalian circadian clocks regulate the concentration of many reproductive hormones (Lucas and Eleftheriou, 1980; Clair et al., 1985; Chappell et al., 2003; Miller et al., 2004). There is also evidence that circadian cycles influence the link between metabolic processes and reproductive physiology since obesity has been shown to have an important impact on fertility through its contribution to anovulation. Obesity may also increase miscarriage rates. Besides, obese women have a higher chance of developing gestational diabetes and preeclampsia (DeUgarte et al., 2010).

Chronotherapy has been applied as a promising technique for the treatment of various diseases and physiological changes. It has been used in the treatment of obesity and metabolic syndromes after taking into consideration three important aspects of circadian system organization: 1) the action of the central oscillator governing the time of food intake and the performance of physical activity during the day; 2) the individual's genetic makeup through the detection of genes that predispose the development of metabolic imbalances; 3 ) the administration of drugs in a way that follows the release rhythms of cortisol, melatonin, and other compounds that are involved in the control of metabolic pathways and expressed in a circadian pattern (Gómez-Abellán et al., 2012).

Because the components of the molecular circadian system operate in the overall control of metabolic homeostasis (disorders which can further increase body weight), it is necessary to investigate natural products that, when ingested, could aid in weight control, which, in turn, would improve fertility in overweight females.

Genetics and Molecular Research 16 (2): gmr16029605 
The aim of this study was to evaluate how the administration of an aqueous green tea extract at different times of the day would affect mice on different diets (regular and high glucose) and how this extract influences lipid metabolism and the synthetic activity of the liver, adipose tissue, and ovaries. Another goal of this study was to monitor changes in body weight, blood glucose levels (glycemia), and food intake, as well as in the structural organization of white adipose tissue (WAT) under these experimental conditions.

\section{MATERIAL AND METHODS}

Experiments were performed using 20 female Swiss mice (Mus musculus) that were approximately 4 months of age. They were supplied by the vivarium of Sagrado Coração University (USC) in São Paulo State, Brazil. The animals were cared for following Brazilian Animal Welfare Regulations, or the CONCEA (2013), which is monitored by the Brazilian Institutional Animal Care and Use Committee (CONCEA) during the experiments. The animals were kept in cages at a controlled temperature (between $21^{\circ}$ and $25^{\circ} \mathrm{C}$ ), and with a 12:12-h light:dark cycle. Food and water were offered ad libitum. The animals were euthanized through the injection of barbiturates and cervical dislocation for biological material collection. All procedures used for euthanasia were consistent with CONCEA (2013) Euthanasia Practice Guidelines. This project was approved by the Ethics Committee for Animal Research and Education from University of São Paulo, School of Dentistry - Bauru Campus (FOB-USP) under protocol No. 004/2013.

\section{Experimental design}

The 20 mice were first separated into 2 groups $(\mathrm{N}=10 /$ group $)$ for a 7-day acclimatization period, followed by a 20-day initial experimental period. One of the groups was fed the control diet, while the other one was fed a high-glucose diet $(\cong+2500 \mathrm{kcal} / \mathrm{kg})$. Pellets for this high-glucose diet were created by mixing $1000 \mathrm{~g}$ control diet powder, 1000 $\mathrm{g}$ sucrose, and $1200 \mathrm{~g}$ sweetened condensed milk ( $\cong 55 \%$ simple sugar, $8 \%$ fat, $8 \%$ protein, w/w, Nestlé). Daily food intake, weekly body weight, and weekly glycemia levels were recorded during both the acclimatization period and the first 20 days of the experimental period. In the second 20-day experimental period, the animals were separated into the 4 following groups ( $\mathrm{N}=5$ /group): the LPCD group, which received the control diet and green tea $1 \mathrm{~h}$ after the start of the light phase; the DPCD group, which received the control diet and green tea $1 \mathrm{~h}$ after the start of the dark phase; the LPHGD group, which received the high-glucose diet and green tea $1 \mathrm{~h}$ after the start of the light phase; and the DPHGD group, which received the high-glucose diet and green tea $1 \mathrm{~h}$ after the start of the dark phase. A minimum of 5 animals per group was chosen to enable statistical analysis. Aqueous green tea extract was prepared by adding $1 \mathrm{~L}$ distilled water to $200 \mathrm{~g}$ powdered plant material in a 2.5-L glass flask and then boiling for $20 \mathrm{~min}$. The solution was subsequently filtered using filter paper, and aliquots were made from the filtrate. They were kept at $4^{\circ} \mathrm{C}$ for 3 to 4 days until use. Treatment with aqueous green tea extracts $\left(0.2 \mathrm{~g} \cdot \mathrm{kg}^{-1} \cdot \mathrm{day}^{-1}\right)$ was performed for 20 days via gavage. Dosage and concentration of green tea extracts were calculated according to Valenzuela (2004) and Khan and Mukhtar (2007).

At the end of the experimental period, the animals were euthanized, and the tissues (liver, WAT, and ovaries) were collected and prepared for specific analysis.

Genetics and Molecular Research 16 (2): gmr16029605 


\section{Adipose tissue: histological sections}

WAT located in the abdominal cavity was used in this analysis. WAT fragments were fixed in $10 \%$ buffered formalin for $24 \mathrm{~h}$ and embedded in paraffin. Histological sections of 3 $\mu \mathrm{m}$ were obtained in microtome Leica RM 2145 and submitted to hematoxylin-eosin (HE) staining. The number and area of adipocytes were measured in 5 histological sections per animal. Ten images were taken of each section. All images were obtained using a Nikon Eclipse 80i microscope with Image-Pro ${ }^{\circledR}$ Plus, version 5.1.2 for Windows XP Media Cybernetics, Inc. All measures were taken using Image J - Image Processing and Analysis in Java, Version 1.40 (http://rsb.info.nih.gov/ij/).

\section{Total protein extraction and immunoblotting}

Medial fragments of the larger lobe of the liver, WAT located in the abdominal cavity fragments as well as both ovaries per animal ( $100 \mathrm{mg}$ each) were homogenized in $1000 \mu \mathrm{L}$ RIPA buffer containing inhibitors ( $1 \mathrm{M} \mathrm{NaF}$, complete protease cocktail inhibitor, and 0.1 M PMSF). Next, the product was centrifuged at $14,000 \mathrm{~g}$ for $15 \mathrm{~min}$ at $4^{\circ} \mathrm{C}$. The supernatant was removed after centrifugation. The total extracted proteins were quantified using the NanoDrop 2000 spectrophotometer (Thermo Scientific ${ }^{\circledR}$ ). The proteins were diluted in RIPA buffer with inhibitors to homogenize the quantities. They were then diluted in Laemmli buffer and stored at $-20^{\circ} \mathrm{C}$ until use.

For the immunoblot assay, approximately $25 \mu \mathrm{g}$ protein obtained from a pool of protein extracts from each animal was separated on $10 \%$ SDS-polyacrylamide gel and transferred to a PVDF membrane using electroblotting. Next, the membranes were washed in PBST and incubated for $1 \mathrm{~h}$ at room temperature in 5\% nonfat milk/PBST to block non-specific staining. After incubation, the membranes were again washed in PBST and incubated with the antifibrillarin [38F3] primary antibody ab4566 at 1:2000, the LXRa $(\mathrm{H}-7)$ antibody sc-377260 at 1:500 (Santa Cruz Biotechnology), and the T5168 anti- $\alpha$-Tubulin antibody at 1:10,000 (SigmaAldrich), all of which were diluted in $5 \%$ nonfat milk/PBST and incubated overnight at $4{ }^{\circ} \mathrm{C}$.

After incubation with the primary antibodies, the membranes were again washed in PBST and were then incubated with a secondary antibody (HRP Rabbit anti-mouse-Invitrogen $616520)$ at 1:4000. The antibody was diluted in 5\% nonfat milk/PBST, and incubation took place for $1 \mathrm{~h}$ at room temperature. Finally, the membranes were washed in PBST and dried, and the images were quantified.

\section{Statistical analysis}

Normal distribution of the dataset was tested using skewness and kurtosis analysis (Ha and Ha, 2007), and variance homogeneity was tested using the F max test (Zar, 1999). The Kruskal-Wallis $\mathrm{H}$ test was chosen to analyze variations in body weight, glycemia, and food consumption in the 3 first weeks of the experiment (without green tea intake) compared to the 3 last weeks of the experiment (with green tea intake) among the four groups (LPCD, LPHGD, DPCD, and DPHGD.) Kruskal-Wallis ANOVA was used to evaluate variations in the number and size of adipocytes among the four groups at the end of the experimental period. The sizes of the bands detected by Western blot performed to determine the presence of LXRa $\beta$, fibrillarin, and tubulin in the liver, WAT, and ovaries were compared between the four groups using Kruskal-Wallis ANOVA.

Genetics and Molecular Research 16 (2): gmr16029605 
Statistical analyses were performed according to Zar (1999) using the StatSoft, Inc. software (2011) and the STATISTICA data analysis software system, version 10. Findings were considered statistically significant when $\mathrm{P} \leq 0.05$.

\section{RESULTS}

\section{Body weight}

Body weight was measured weekly before and after the green tea extract treatment. Means were compared every week before the green tea treatment (weeks 1,2, and 3) and every week after the green tea treatment (weeks 4, 5, and 6), and the results are shown in Figure 1A, $\mathrm{B}, \mathrm{C}$, and $\mathrm{D}$.

Figure $1 \mathrm{~A}$ and $\mathrm{B}$ show a decrease in body weight after the treatment with green tea extracts in the groups whose green tea was administered in the light phase of the day in both the regular and the high-glucose diet groups. Groups whose green tea was administered in the dark phase of the day exhibited no difference in body weight after the short-term treatment (Figure $1 \mathrm{C}$ and D).
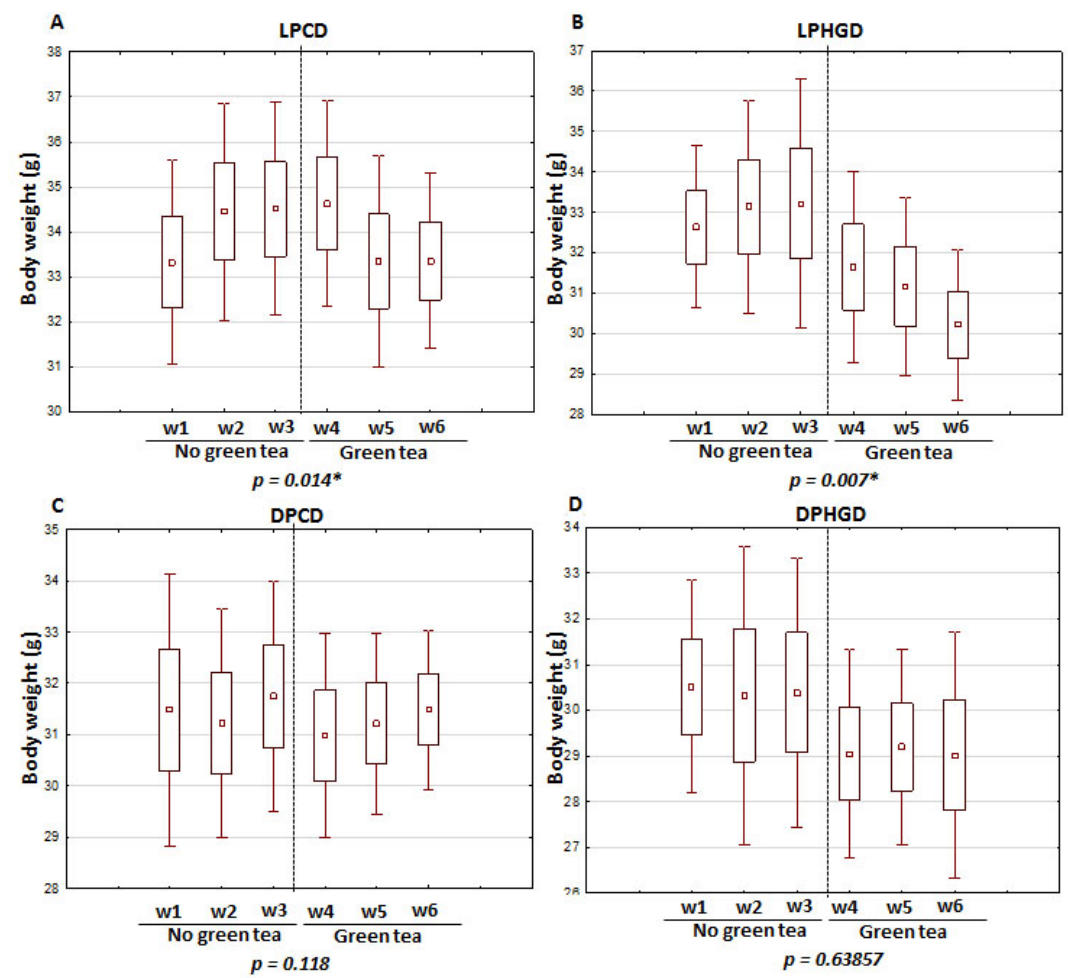

Figure 1. Weekly variation of body weight $(\mathrm{g})$ in the four experimental groups before and after the treatment with green tea. A. and B. LPCD group = received the control diet and green tea $1 \mathrm{~h}$ after the start of the light phase; DPCD group $=$ received the control diet and green tea $1 \mathrm{~h}$ after the start of the dark phase. C. and D. LPHGD group $=$ received the high-glucose diet and green tea $1 \mathrm{~h}$ after the start of the light phase; DPHGD group = received the high-glucose diet and green tea $1 \mathrm{~h}$ after the start of the dark phase.

Genetics and Molecular Research 16 (2): gmr16029605 


\section{Glucose levels}

Glucose levels were measured weekly before and after treatment with green extracts. Means were compared every week before treatment (weeks 1,2 and 3) and every week after treatment (weeks 4, 5, and 6). The effects of the green tea treatment on blood glucose levels are shown in Figure 2A, B, C, and D.

High variability in glucose levels was observed over the course of the experimental period. Although there was a decrease in glucose levels in DPCD and DPHGD groups in the second week after the green tea treatment (week 5), the same results did not persist into the third week (week 6) (Figure 2C and D).
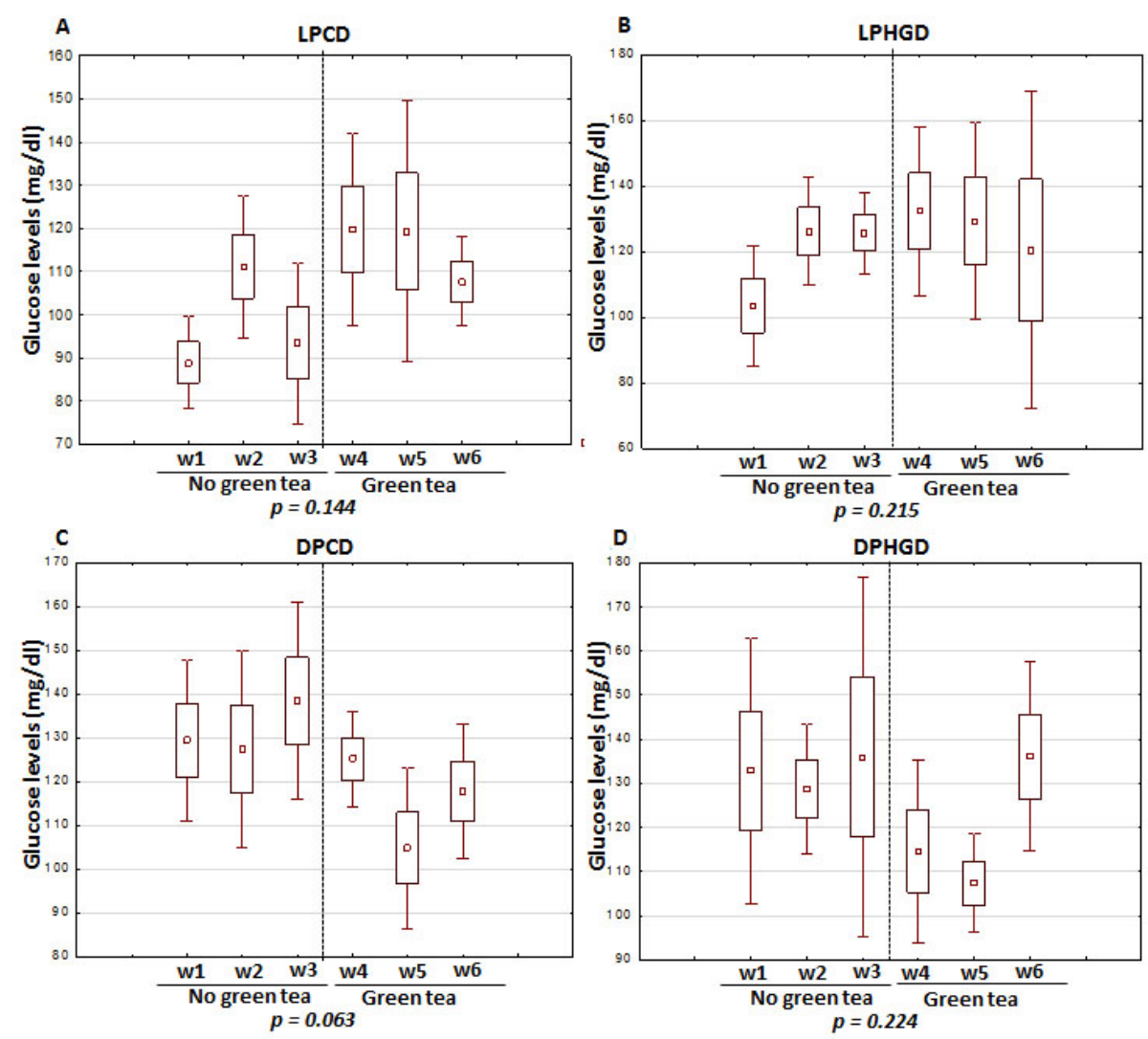

Figure 2. Weekly variation of circulating glucose levels $(\mathrm{mg} / \mathrm{dL})$ in the four experimental groups before and after the treatment with green tea. For group descriptions, see legend to Figure 1.

\section{Food intake}

Food intake was measured daily before and after the green tea extract treatment. The mean quantities of food consumed were compared every week before the green tea treatment (weeks 1,2, and 3) and every week after treatment (weeks 4, 5, and 6), and the results are shown in Figure 3A, B, C, and D. 
All groups were found to decrease the amount of food ingested after the green tea treatment (Figure 3A, B, C, and D).
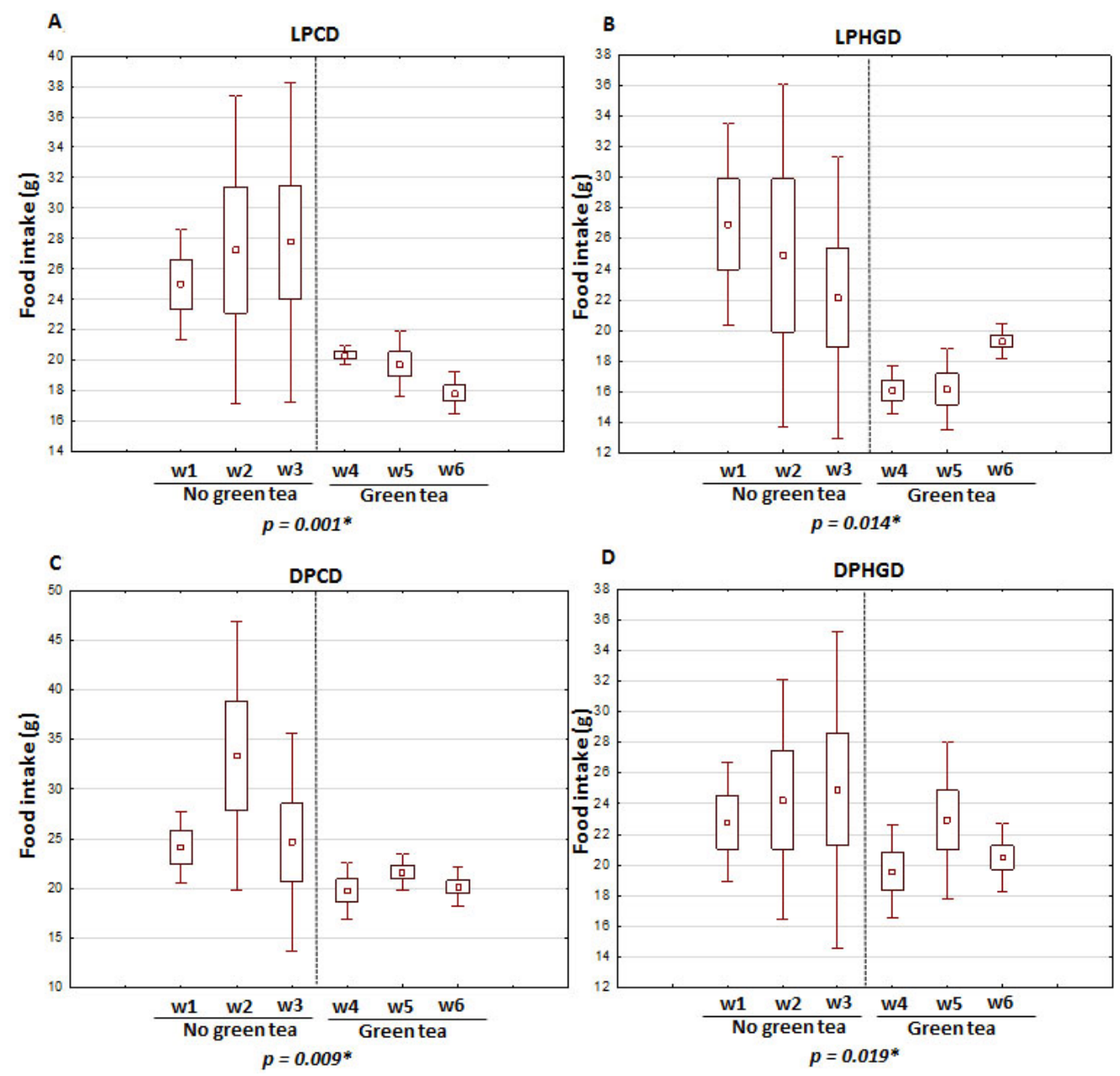

Figure 3. Weekly variation of food intake $(\mathrm{g})$ in the four experimental groups before and after the treatment with green tea. For group descriptions, see legend to Figure 1.

\section{Size and number of adipocytes in the abdominal WAT}

Animals from the DPHGD group exhibited larger adipocytes when compared to adipocytes from animals in the LPCD group $(\mathrm{P}=0.0488)$. There were no other significant differences in adipocyte size among the groups (Figure 4).

As Figure 5 shows, no statistical differences were detected when the quantities of adipocytes were compared among the groups after the green tea treatment $(\mathrm{P}=0.0695)$. The data on the adipocytes in the WAT of animals from each experimental group can be found in Figure 6 .

Genetics and Molecular Research 16 (2): gmr16029605 


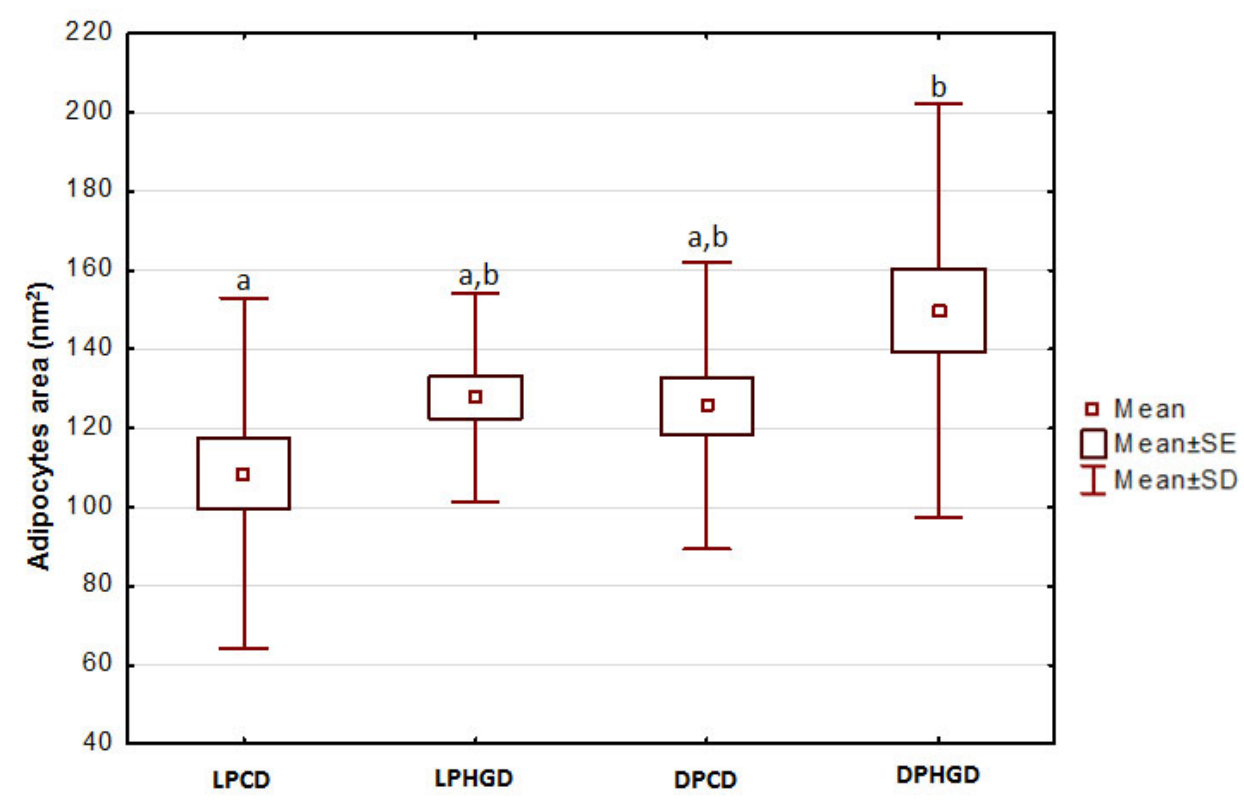

Figure 4. Mean area $\left(\mathrm{nm}^{2}\right)$ of the adipocytes of animals from each experimental group after the 3-week period of treatment with green tea. For group descriptions, see legend to Figure 1.

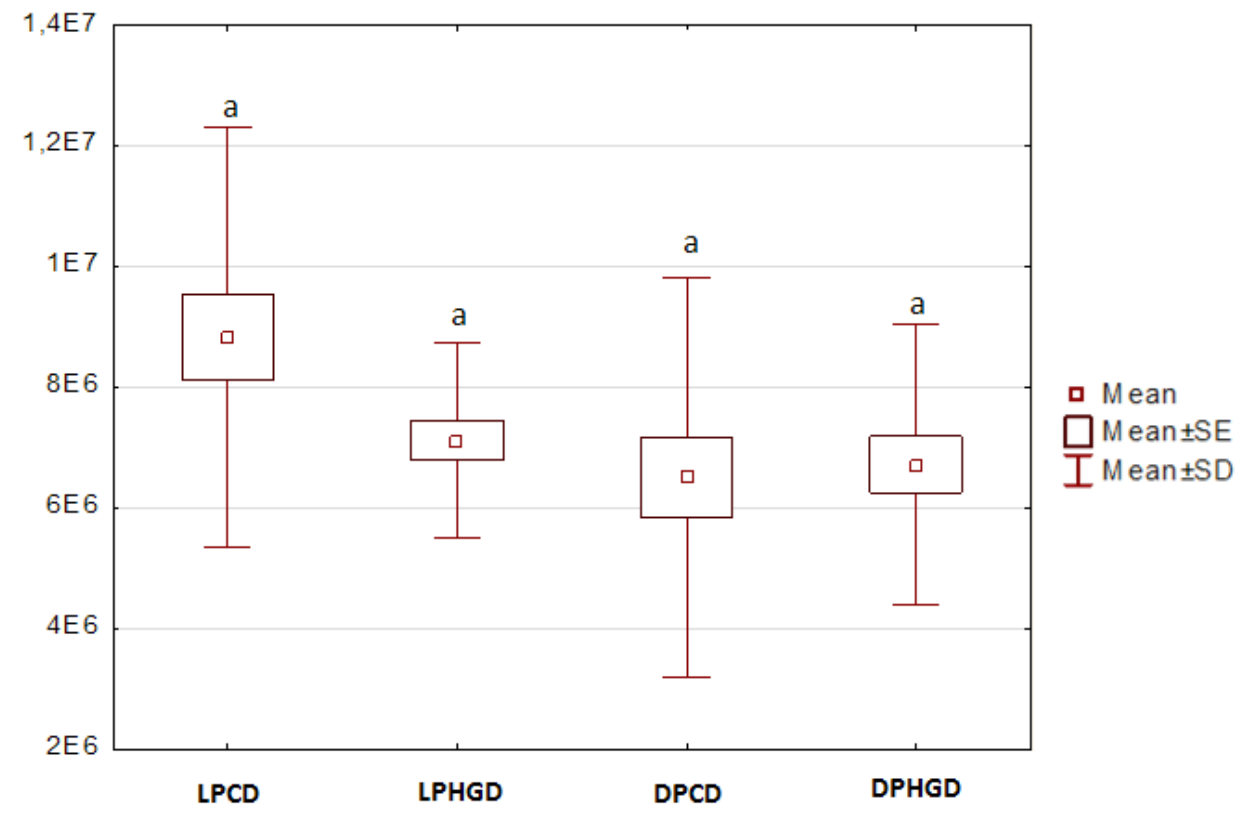

Figure 5. Mean number of the adipocytes of animals from each experimental group after the 3-week treatment period with green tea. For group descriptions, see legend to Figure 1.

Genetics and Molecular Research 16 (2): gmr16029605 

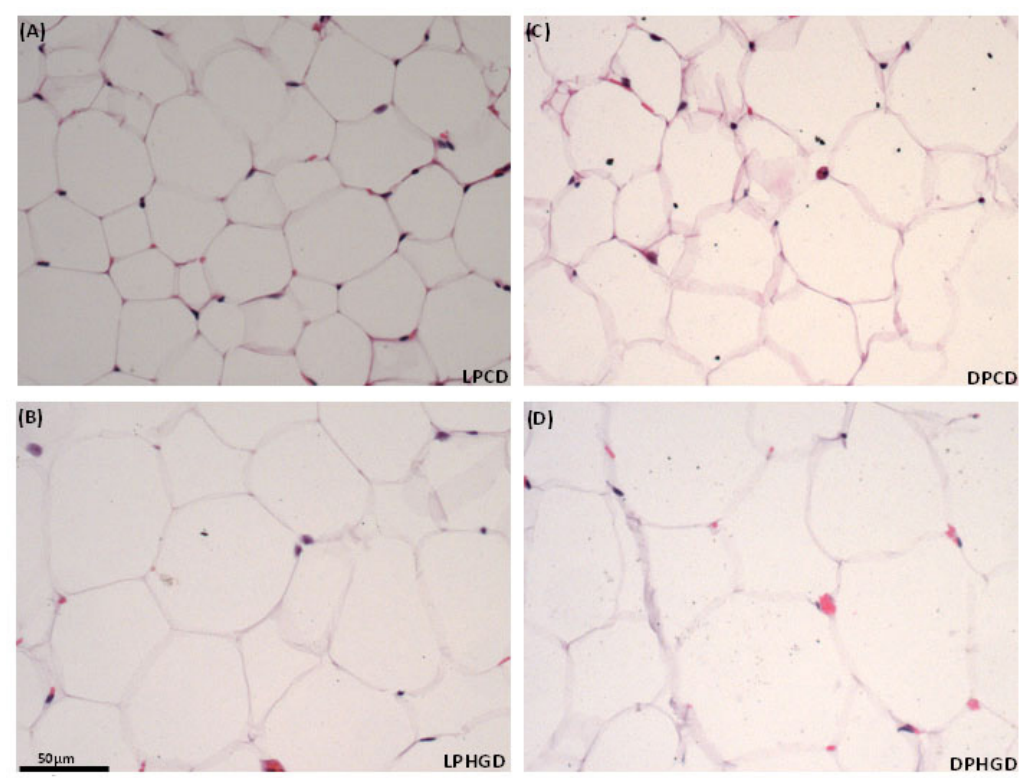

Figure 6. Micrographs showing the adipocytes of animals of each experimental group. For group descriptions, see legend to Figure 1.

\section{Expression of the LXRaß receptor and fibrillarin in the liver, WAT, and ovaries}

Higher LXRa $\beta$ quantities were observed in the livers of animals from the LPCD and DPHGD groups (Figure 7). The same variation was not observed in the WAT (Figure 8). There was no difference in the extent of nucleolar protein fibrillarin expression among the groups in any of these tissues (Figures 7 and 8).

A
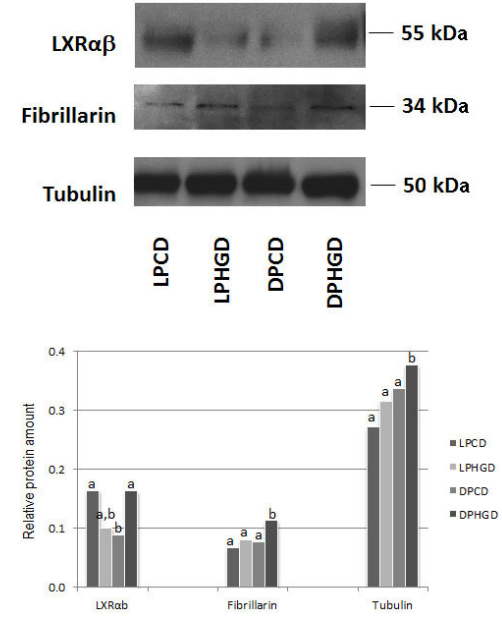

Figure 7. Expression of the LXRa $\beta$ receptor and the nucleolar protein fibrillarin in the liver of animals of each experimental group after the 3 -week period of treatment with green tea. Tubulin expression was used as a reaction control. For group descriptions, see legend to Figure 1.

Genetics and Molecular Research 16 (2): gmr16029605 
A

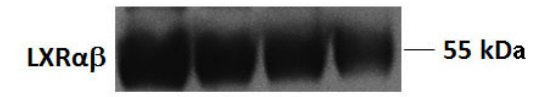

Fibrillarin

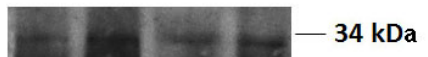

Tubulin

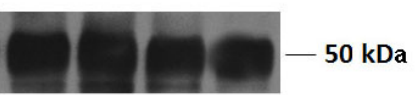

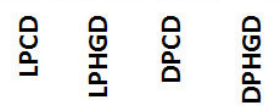

B

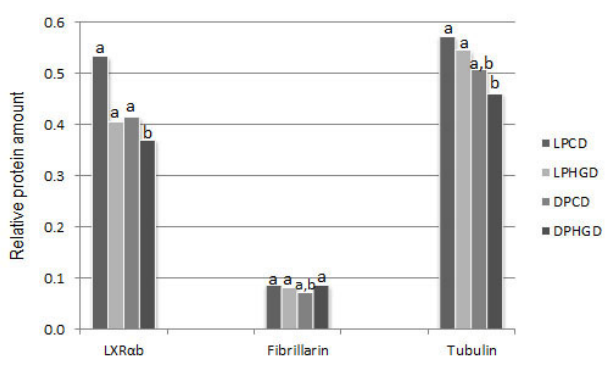

Figure 8. Expression of the LXRa $\beta$ receptor and the nucleolar protein fibrillarin in the white adipose tissue of animals of each experimental group after the 3-week period of treatment with green tea. Tubulin expression was used as a reaction control. For group descriptions, see legend to Figure 1.

Higher LXRa $\beta$ expression and nucleolar protein fibrillarin levels were observed in the ovaries of the LPHGD and DPCD groups, which were kept under different food conditions and which received green tea at different times (Figure 9).

A

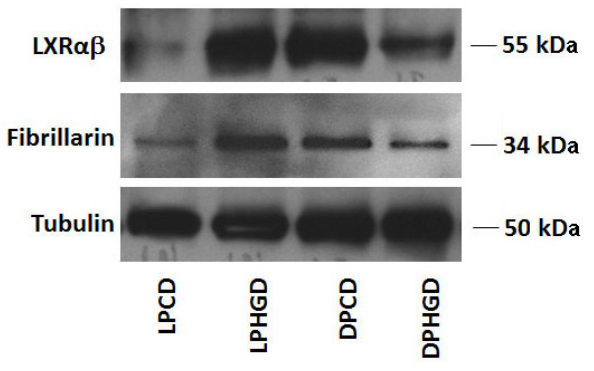

B

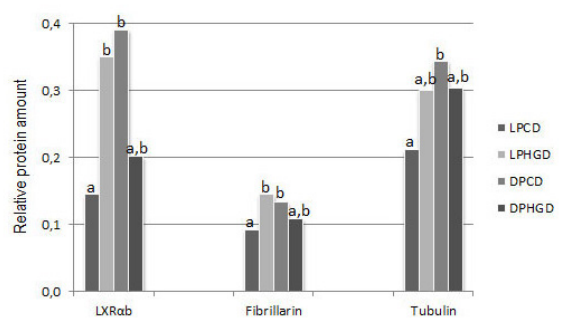

Figure 9. Expression of the LXRa $\beta$ receptor and the nucleolar protein fibrillarin in the ovaries of animals of each experimental group after the 3 -week period of treatment with green tea. Tubulin expression was used as a reaction control. For group descriptions, see legend to Figure 1.

Genetics and Molecular Research 16 (2): gmr16029605 
A complete summary of the results of this study can be found in Table 1 .

\begin{tabular}{|c|c|c|c|c|}
\hline \multirow[t]{2}{*}{ Variables } & \multicolumn{4}{|c|}{ Experimental groups } \\
\hline & LPCD & LPHGD & DPCD & DPHGD \\
\hline Body weight & $\downarrow *$ & $\downarrow *$ & $=$ & $=$ \\
\hline Glycemia & $=$ & $=$ & $\downarrow ?$ & $\downarrow ?$ \\
\hline Food consumption & $\downarrow *$ & $\downarrow *$ & $\downarrow *$ & $\downarrow *$ \\
\hline Adipocyte area & $\downarrow *$ & $=$ & $=$ & $\uparrow *$ \\
\hline Adipocyte number & $=$ & $=$ & $=$ & $=$ \\
\hline LXR $\alpha \beta$ liver expression & 个* & $=$ & $=$ & $\uparrow *$ \\
\hline LXR $\alpha \beta$ adipose tissue expression & $=$ & $=$ & $=$ & $=$ \\
\hline LXR $\alpha \beta$ ovary expression & $=$ & 个* & $\uparrow *$ & $=$ \\
\hline Fibrillarin liver expression & $=$ & $=$ & $=$ & $=$ \\
\hline Fibrillarin adipose tissue expression & $=$ & $=$ & $=$ & $=$ \\
\hline Fibrillarin ovary expression & $=$ & 个* & 个* & $=$ \\
\hline
\end{tabular}

Data on weight, glucose levels, and food intake were obtained before and after treatment with green tea and are shaded in gray. All other data were collected only at the end of the experimental period of treatment with green tea. Asterisks represent changes with statistically significant differences. For group descriptions, see legend to Figure 1.

\section{DISCUSSION}

\section{Evaluation of the general physiological parameters}

In this study, the animals that received the oral administration of aqueous Camellia sinensis (green tea) extract for 20 days in the light phase of the day exhibited significant weight loss, regardless of their diet (regular versus high glucose). Recent literature has demonstrated these effects of green tea extracts (composed primarily of caffeine and catechins) on body weight maintenance through the activation of energy expenditure, fat oxidation, and the preservation of fat-free body mass (Janssens et al., 2016).

Caffeine and catechins, which are two of the main components of aqueous green tea extracts, possess the ability to amplify the pathways that act upon the activation of noradrenaline, which has a positive effect on thermogenesis and which boosts energy expenditure when both components are present (Türközü and Tek, 2017). Interestingly, the groups that exhibited a reduction in body weight by the end of the short green tea administration period were only those that received the extract in the light phase of the day (LPCD and LPHGD groups). This finding indicates that the actions of the green tea components involved in the thermogenic pathway are likely to occur through the expression of the genes involved in this mechanism, which is controlled by circadian rhythms, regardless of nutritional conditions (Masri and Sassone-Corsi, 2010). Some studies have reported that exercise also has an effect of increasing thermogenic activity similar to that of the green tea components (Levy et al., 2016).

Overall, there was substantial variation in glucose levels over the course of the experiment. This change may be explained by the short experimentation period and the lack of control based on the animals' genetic histories. Another interesting finding was the observation that, in the second week of treatment, glucose levels declined in the groups that received green tea in the dark phase of the day (DPCD and DPHGD groups), regardless of diet; however, the results did not persist into the third week. The increase in circulating glucose levels triggers

Genetics and Molecular Research 16 (2): gmr16029605 
the process of insulin production and secretion by the beta cells of the pancreas so that insulin may aid in the absorption of glucose by the muscles, adipose tissue, and liver, as well as in the conversion of glucose into glycogen by these same organs and the reduction in glucose production by the liver (National Institute of Diabetes and Digestive and Kidney Diseases, 2016; Storlien et al., 2016). In the current study, only the groups that received green tea in the dark phase of the day exhibited a tendency toward lower blood glucose levels; therefore, the production of insulin in response to glucose consumption may be affected by the green tea components through the amplification of the insulin secretion pathways that are under circadian control, as has been proposed in other studies such as Harfmann et al. (2016). However, the increase in circulating glucose levels (even after 3 weeks of green tea treatment) observed primarily in the DPHGD group may indicate that these elevated glucose index levels resulting from this group's diet may both inhibit the effects of green tea and cause a tendency toward insulin resistance. The latter phenomenon may generate an overload for the pancreas, which is a predisposing factor in the development of type 2 diabetes (National Institute of Diabetes and Digestive and Kidney Diseases, 2016; Storlien et al., 2016).

Significant differences were also detected in food consumption in the periods before and after the administration of $C$. sinensis in all of the experimental groups. Kao et al. (2000) and Lamarao and Fialho (2009) have provided evidence that a green tea extract containing $25 \%$ EGCG may reduce appetite and increase the catabolism of fats. According to these same authors, the effects of EGCG on endocrine parameters is explained by its secondary effect on food intake, which is reflected in the decrease in circulating leptin in mice treated with this catechin. This change is likely instigated by the reduction in stored fat that occurs through the decreased food intake. Although the role that the circadian rhythm plays in food intake behavior and in maintaining metabolism is widely recognized (Almoosawi et al., 2016), the mechanisms by which green tea regulates food intake do not seem to be governed by circadian rhythms: in the current study, all groups exhibited lower food intake, regardless of the type of diet or the time at which green tea was consumed.

\section{LXRaß and nucleolar protein fibrillarin expression in the liver, WAT, and ovaries}

Changes in $L X R a \beta$ expression were observed only in the liver and ovarian tissues from the different experimental groups. The LPCD and DPHGD groups exhibited greater LXRa $\beta$ expression in the liver and lower LXRa $\beta$ expression in the ovary relative to the LPHGD and DPCD groups, which exhibited an opposite pattern (lower expression in the liver and higher expression in the ovaries).

LXR is a protein responsible for protecting cells from cholesterol overload, thus stimulating the expression of cholesterol-transporting enzymes and their conversion into biliary acids and biliary excretion (Bełtowski and Semczuk, 2010). LXR also participates in the anti-inflammatory mechanisms of certain cell types, since it acts as an anti-inflammatory response modulator and upon the metabolism of lipids on macrophages and can thus help to reduce the inflammation associated with obesity (Yoo et al., 2011).

In an experiment involving the administration of estradiol-17 $\beta$ (E2) in mice that did not express estrogen $\alpha$ receptors (ER $\alpha$ KO mice), Han et al. (2014) demonstrated that the administration of E2 reduces the expression of the sterol- regulatory element-binding protein (SREBP-1) and induces the accumulation of triglycerides in the liver in the activation of LXR through a nonclassical pathway in this tissue. The current experiment showed that the

Genetics and Molecular Research 16 (2): gmr16029605 
LPHGD and DPCD groups exhibited lower LXR levels in the liver and, as a consequence, a lower accumulation of triglycerides in the organ. Interestingly, these same groups exhibited high levels of LXR in the ovarian tissue. LXR activates lipogenesis by increasing SREBP-1 expression which, in turn, controls key genes involved in the biosynthesis of fatty acids and thus contributes both to the progression of gametogenesis and to steroidogenesis in the gonads (Horton et al., 2002). Thus, high LXR expression in the ovaries of the LPHGD and DPCD groups may favor the physiology of the gonads of the animals in these experimental groups.

Fibrillarin (also known as B36) is found in the fibrillar center (FC) and the dense fibrillar component (DFC) of the nucleolus. This protein is part of the box C/D and H/ACA snoRNP complexes of this nuclear compartment. The box C/D and H/ACA snoRNP complexes are responsible for processing pre-RNArs through post-transcriptional modifications, methylation-2'-O and pseudouridylation (review by Morimoto and Boerkoel, 2013).

The presence of active nucleoli is necessary for both ribosome production and the control of cell proliferation and survival (Carmo-Fonseca et al., 2000). Therefore, nucleolar activity is indispensable in ovarian follicular proliferation, which enables female reproductive activity (Morimoto and Boerkoel, 2013). It is important to note that the groups with the highest LXR expression in the ovaries were also the groups that had the highest fibrillarin expression in this tissue. This finding indicates that this increase in nucleolar activity may contribute to the overall increase in protein synthesis in ovarian tissue, and may even contribute to the increases in the expression of ER $\alpha$ and SREBP-1, proteins that play important roles in reproduction, in the control of food intake, and in the metabolism of glucose and lipids (Faulds et al., 2012).

The analysis of fibrillarin expression in the liver and adipose tissue demonstrated that there was no association between food quality and the period in which green tea was administered since all groups exhibited the same amount of fibrillarin. Classic studies have shown that the structural organization and activity of the nucleolus are controlled by circadian rhythms in certain cell types (Seïte and Pebusque, 1985). The results of the current study provide evidence that the components of green tea studied herein have no effect on this pathway, regardless of diet or the time of day the green tea extract was consumed.

\section{Physiology of the liver and adipose tissue and the structural organization of adipose tissue in the groups fed a high-glucose diet}

Adipocytes do not only accumulate lipids, they also play an important role in controlling energy expenditure through the release of a series of adipokines (Al-Daghri et al., 2015). There are two main types of adipose tissue: WAT, which is involved in the accumulation of triglycerides and the increase of which may lead to obesity; and brown adipose tissue, which metabolizes fatty acids to maintain body temperature (Cannon and Nedergaard, 2004). It is important to note that the imbalance in energy homeostasis has led to a substantial increase in obesity around the world and that obesity is frequently associated with the development of other metabolic syndromes, such as diabetes and hypertension (Lin, 2015). In the current experimental model, there were two groups that received the high-glucose diet and green tea, one group that received the green tea extract in the light phase of the day (the LPHGD group), and a third that received the extract in the dark phase of the day (the DPHGD group). The LPHGD group exhibited low LXR expression in the liver, which likely resulted in low triglyceride accumulation in the organ; this group also exhibited WAT with relatively low LXR expression.

Genetics and Molecular Research 16 (2): gmr16029605 
The association between the molecules involved in lipid metabolism (such as the LXR receptor) and the consumption of glucose-rich diets is relevant in our experimental model since lipid metabolism and glucose metabolism are intrinsically related and both are regulated by the liver (Parhofer, 2015). Furthermore, it is well known that diabetes patients frequently experience cases of dyslipidemia characterized by an increase in triglycerides, low HDL-C, and high LDL (Wu and Parhofer, 2014). By offering glucose-rich foods to the mice in the highglucose groups in this experimental model, we simulated the dyslipidemia situation observed in human diabetic patients. The animals in the LPHGD group exhibited a good response to this condition; however, given the low expression of LXR in their livers, they likely did not exhibit high triglyceride levels.

In an experiment with mice that were heterozygous for the eukaryotic translation initiation factor 6 (eIF6) gene, which controls translation and initiation factors, Gandin et al. (2008) found that a reduction in the ribosome biogenesis and in the indices of translation led to a reduction in adipose tissue mass; this reduction is associated with a decrease in the rate of cell proliferation. Between the groups fed with the high-glucose diet in the current experimental model, the LPHGD group was found to follow this pattern. The mice maintained low fibrillarin expression in adipose tissue, which indicates low nucleolar activity and low ribosome biogenesis. They also presented a smaller area of adipocytes when compared to the DPHGD group.

In conclusion, food quality and the time of the day when Camellia sinensis was administered were found to have different effects on metabolic physiology. Between the groups that received a high-glucose diet, the LPHGD group most clearly exhibited the expected protective effect after the consumption of this extract: the mice in this group exhibited decreases in both body weight and food consumption, as well as low LXRa $\beta$ levels in the liver and high LXRa $\beta$ and fibrillarin levels in the ovaries.

\section{Conflicts of interest}

The authors declare no conflict of interest.

\section{ACKNOWLEDGMENTS}

Research supported by the São Paulo Research Foundation (FAPESP, grants \#2012/22009-7, \#2014/07243-9, and \#2014/15975-0), as well as by the Brazilian Research Council (CNPq, grants \#137101/2013-9 and \#155469/2014-2. We thank Dr. Tiago da Silveira Vasconcelos and Danielle Jacqueline Deremo Cosimo for critical reading of the manuscript. We also thank all members of the Laboratory of Molecular Biology and Cytogenetics (USC) for help, stimulating discussions and reagents. Special thanks to Gabriel Manuel da Silva, a high school student in the lab.

\section{REFERENCES}

Al-Daghri NM, Al-Attas OS, Krishnaswamy S, Mohammed AK, et al. (2015). Association of Type 2 Diabetes Mellitus related SNP genotypes with altered serum adipokine levels and metabolic syndrome phenotypes. Int. J. Clin. Exp. Med. 8: 4464-4471.

Almoosawi S, Vingeliene S, Karagounis LG and Pot GK (2016). Chrono-nutrition: a review of current evidence from

Genetics and Molecular Research 16 (2): gmr16029605 
observational studies on global trends in time-of-day of energy intake and its association with obesity. Proc. Nutr. Soc. 75: 487-500. http://dx.doi.org/10.1017/S0029665116000306

Asher G and Schibler U (2011). Crosstalk between components of circadian and metabolic cycles in mammals. Cell Metab. 13: 125-137. http://dx.doi.org/10.1016/j.cmet.2011.01.006

Bellet MM and Sassone-Corsi P (2010). Mammalian circadian clock and metabolism - the epigenetic link. J. Cell Sci. 123: 3837-3848. http://dx.doi.org/10.1242/jcs.051649

Bełtowski J and Semczuk A (2010). Liver X receptor (LXR) and the reproductive system--a potential novel target for therapeutic intervention. Pharmacol. Rep. 62: 15-27. http://dx.doi.org/10.1016/S1734-1140(10)70239-5

Boden MJ and Kennaway DJ (2006). Circadian rhythms and reproduction. Reproduction 132: 379-392. http://dx.doi. org/10.1530/rep.1.00614

Borges CM, Papadimitriou A, Duarte DA, Lopes de Faria JM, et al. (2016). The use of green tea polyphenols for treating residual albuminuria in diabetic nephropathy: A double-blind randomised clinical trial. Sci. Rep. 6: 28282. http:// dx.doi.org/10.1038/srep28282

Cannon B and Nedergaard J (2004). Brown adipose tissue: function and physiological significance. Physiol. Rev. 84: $277-$ 359. http://dx.doi.org/10.1152/physrev.00015.2003

Carmo-Fonseca M, Mendes-Soares L and Campos I (2000). To be or not to be in the nucleolus. Nat. Cell Biol. 2: E107-E112. http://dx.doi.org/10.1038/35014078

Chanadiri T, Sanikidze T, Esaishvili M, Chkhikvishvili I, et al. (2005). [Effectiveness of green tea catechines for the correction of the alimentary obesity in the experiment]. Georgian Med. News 126: 61-63.

Chappell PE, White RS and Mellon PL (2003). Circadian gene expression regulates pulsatile gonadotropin-releasing hormone $(\mathrm{GnRH})$ secretory patterns in the hypothalamic GnRH-secreting GT1-7 cell line. J. Neurosci. 23: 1120211213.

Clair P, Claustrat B, Jordan D, Dechaud H, et al. (1985). Daily variations of plasma sex hormone-binding globulin binding capacity, testosterone and luteinizing hormone concentrations in healthy rested adult males. Horm. Res. 21: 220-223. http://dx.doi.org/10.1159/000180052

CONCEA (2013). Diretrizes Brasileiras Para o Cuidado e a Utilização de Animais Para Fins Científicos e Didáticos (DBCA). Available at [file:///C:/Users/Pc\%202/Downloads/DBCA\%20CONCEA.pdf].

DeUgarte DA, DeUgarte CM and Sahakian V (2010). Surrogate obesity negatively impacts pregnancy rates in third-party reproduction. Fertil. Steril. 93: 1008-1010. http://dx.doi.org/10.1016/j.fertnstert.2009.07.1005

Diepvens K, Westerterp KR and Westerterp-Plantenga MS (2006). Obesity and thermogenesis related to the consumption of caffeine, ephedrine, capsaicin and green tea. Am. J. Physiol. Regul. Integr. Comp. Physiol. 13: 77-85. http://dx.doi. org/10.1152/ajpregu.00832.2005

Dulloo AG, Duret C, Rohrer D, Girardier L, et al. (1999). Efficacy of a green tea extract rich in catechin polyphenols and caffeine in increasing 24-h energy expenditure and fat oxidation in humans. Am. J. Clin. Nutr. 70: 1040-1045.

Faulds MH, Zhao C, Dahlman-Wright K and Gustafsson J-A (2012). The diversity of sex steroid action: regulation of metabolism by estrogen signaling. J. Endocrinol. 212: 3-12. http://dx.doi.org/10.1530/JOE-11-0044

Froy O (2010). Metabolism and circadian rhythms--implications for obesity. Endocr. Rev. 31: 1-24. http://dx.doi. org/10.1210/er.2009-0014

Gandin V, Miluzio A, Barbieri AM, Beugnet A, et al. (2008). Eukaryotic initiation factor 6 is rate-limiting in translation, growth and transformation. Nature 455: 684-688. http://dx.doi.org/10.1038/nature07267

Gómez-Abellán P, Madrid JA, Ordovás JM and Garaulet M (2012). Aspectos cronobiológicos de la obesidad y el síndrome metabólico. Endocrinol. Nutr. 59: 50-61. http://dx.doi.org/10.1016/j.endonu.2011.08.002

Gooley JJ (2016). Circadian regulation of lipid metabolism. Proc. Nutr. Soc. 75: 440-450. http://dx.doi.org/10.1017/ $\underline{\mathrm{S} 0029665116000288}$

Ha RR and Ha JC (2007). Integrative statistics for behavioral science. Pearson Custom Publishing, Boston.

Han SI, Komatsu Y, Murayama A, Steffensen KR, et al. (2014). Estrogen receptor ligands ameliorate fatty liver through a nonclassical estrogen receptor/Liver X receptor pathway in mice. Hepatology 59: 1791-1802. http://dx.doi. org/10.1002/hep.26951

Hara R, Wan K, Wakamatsu H, Aida R, et al. (2001). Restricted feeding entrains liver clock without participation of the suprachiasmatic nucleus. Genes Cells 6: 269-278. http://dx.doi.org/10.1046/j.1365-2443.2001.00419.x

Harfmann BD, Schroder EA, Kachman MT, Hodge BA, et al. (2016). Muscle-specific loss of Bmall leads to disrupted tissue glucose metabolism and systemic glucose homeostasis. Skelet. Muscle 6: 12. http://dx.doi.org/10.1186/s13395$\underline{016-0082-\mathrm{x}}$

Horton JD, Goldstein JL and Brown MS (2002). SREBPs: activators of the complete program of cholesterol and fatty acid synthesis in the liver. J. Clin. Invest. 109: 1125-1131. http://dx.doi.org/10.1172/JCI0215593

Genetics and Molecular Research 16 (2): gmr16029605 
Janssens PLHR, Hursel R and Westerterp-Plantenga MS (2016). Nutraceuticals for body-weight management: The role of green tea catechins. Physiol. Behav. 162: 83-87. http://dx.doi.org/10.1016/j.physbeh.2016.01.044

Kao YH, Hiipakka RA and Liao S (2000). Modulation of obesity by a green tea catechin. Am. J. Clin. Nutr. 72: 1232-1234.

Khan N and Mukhtar H (2007). Tea polyphenols for health promotion. Life Sci. 81: 519-533. http://dx.doi.org/10.1016/j. $\underline{\text { Ifs. } 2007.06 .011}$

King DP and Takahashi JS (2000). Molecular genetics of circadian rhythms in mammals. Annu. Rev. Neurosci. 23: 713742. http://dx.doi.org/10.1146/annurev.neuro.23.1.713

Kohsaka A, Laposky AD, Ramsey KM, Estrada C, et al. (2007). High-fat diet disrupts behavioral and molecular circadian rhythms in mice. Cell Metab. 6: 414-421. http://dx.doi.org/10.1016/j.cmet.2007.09.006

Kovacs EMR, Lejeune MPGM, Nijs I and Westerterp-Plantenga MS (2004). Effects of green tea on weight maintenance after body-weight loss. Br. J. Nutr. 91: 431-437. http://dx.doi.org/10.1079/BJN20041061

Lamarao RC and Fialho E (2009). Aspectos funcionais das catequinas do chá verde no metabolismo celular e sua relação com a redução da gordura corporal. Rev. Nutr. 22: 257-269. http://dx.doi.org/10.1590/S1415-52732009000200008

Levy Y, Narotzki B and Reznick AZ (2016). Green tea, weight loss and physical activity. Clin. Nutr. 10.1016/j. clnu.2016.11.001.

Lin JC (2015). Impacts of alternative splicing events on the differentiation of adipocytes. ए. Int. J. Mol. Sci. 16: 2216922189. http://dx.doi.org/10.3390/ijms160922169

Lin J, Della-Fera MA and Baile CA (2005). Green tea polyphenol epigallocatechin gallate inhibits adipogenesis and induces apoptosis in 3T3-L1 adipocytes. Obes. Res. 13: 982-990. http://dx.doi.org/10.1038/oby.2005.115

Lis CG, Grutsch JF, Wood P, You M, et al. (2003). Circadian timing in cancer treatment: the biological foundation for an integrative approach. Integr. Cancer Ther. 2: 105-111. http://dx.doi.org/10.1177/1534735403002002002

Lucas LA and Eleftheriou BE (1980). Circadian variation in concentrations of testosterone in the plasma of male mice: a difference between BALB/cBy and C57BL/6By inbred strains. J. Endocrinol. 87: 37-46. http://dx.doi.org/10.1677/ joe. 0.0870037

Marcheva B, Ramsey KM, Affinati A and Bass J (2009). Clock genes and metabolic disease. J. Appl. Physiol. 107: 16381646. http://dx.doi.org/10.1152/japplphysiol.00698.2009

Masri S and Sassone-Corsi P (2010). Plasticity and specificity of the circadian epigenome. Nat. Neurosci. 13: 1324-1329. http://dx.doi.org/10.1038/nn.2668

Maury E, Ramsey KM and Bass J (2010). Circadian rhythms and metabolic syndrome: from experimental genetics to human disease. Circ. Res. 106: 447-462. http://dx.doi.org/10.1161/CIRCRESAHA.109.208355

Miller BH, Olson SL, Turek FW, Levine JE, et al. (2004). Circadian clock mutation disrupts estrous cyclicity and maintenance of pregnancy. Curr. Biol. 14: 1367-1373. http://dx.doi.org/10.1016/j.cub.2004.07.055

Morimoto M and Boerkoel CF (2013). The role of nuclear bodies in gene expression and disease. Biology (Basel) 2: 9761033. http://dx.doi.org/10.3390/biology2030976

Mota D (2010). Importância dos ritmos circadianos na nutrição e metabolismo. Monografia de Especialização em Ciências da Nutrição e Alimentação, Universidade do Porto, Porto.

National Institute of Diabetes and Digestive and Kidney Diseases (2016). Insulin Resistance and Prediabetes. Available at [https://www.niddk.nih.gov/healthinformation/diabetes/types/prediabetes-insulin-resistance].

Orozco-Solis R, Aguilar-Arnal L, Murakami M, Peruquetti R, et al. (2016). The Circadian Clock in the Ventromedial Hypothalamus Controls Cyclic Energy Expenditure. Cell Metab. 23: 467-478. http://dx.doi.org/10.1016/j. cmet.2016.02.003

Parhofer KG (2015). Interaction between glucose and lipid metabolism: More than diabetic dyslipidemia. Diabetes Metab. J. 39: 353-362. http://dx.doi.org/10.4093/dmj.2015.39.5.353

Ras RT, Zock PL and Draijer R (2011). Tea consumption enhances endothelial-dependent vasodilation; a meta-analysis. PLoS One 6: e16974. http://dx.doi.org/10.1371/journal.pone.0016974

Seïte R and Pébusque MJ (1985). Chronobiological studies on the nucleolus. Chronobiol. Int. 2: 69-91. http://dx.doi. org $/ 10.3109 / 07420528509055546$

Staels B (2006). When the Clock stops ticking, metabolic syndrome explodes. Nat. Med. 12: 54-55, discussion 55. http:// dx.doi.org/10.1038/nm0106-54

Stephan FK (2002). The "other" circadian system: food as a Zeitgeber. J. Biol. Rhythms 17: 284-292. http://dx.doi. org $10.1177 / 074873002129002591$

Stokkan KA, Yamazaki S, Tei H, Sakaki Y, et al. (2001). Entrainment of the circadian clock in the liver by feeding. Science 291: 490-493. http://dx.doi.org/10.1126/science.291.5503.490

Storlien LH, Lam YY, Wu BJ, Tapsell LC, et al. (2016). Effects of dietary fat subtypes on glucose homeostasis during pregnancy in rats. Nutr. Metab. (Lond.) 13: 58. http://dx.doi.org/10.1186/s12986-016-0117-7

Genetics and Molecular Research 16 (2): gmr16029605 
Türközü D and Tek NA (2017). A minireview of effects of green tea on energy expenditure. Crit. Rev. Food Sci. Nutr. 57: 254-258. http://dx.doi.org/10.1080/10408398.2014.986672

Valenzuela A (2004). El consumo te y lasalud: características y propriedades benéficas de esta bebida milenária. Rev. Chil. Nutr. 31: 72-82.

White WB, Elliott WJ, Johnson MF and Black HR (2001). Chronotherapeutic delivery of verapamil in obese versus nonobese patients with essential hypertension. J. Hum. Hypertens. 15: 135-141. http://dx.doi.org/10.1038/sj.jhh.1001137

Wolfram S, Wang Y and Thielecke F (2006). Anti-obesity effects of green tea: from bedside to bench. Mol. Nutr. Food Res. 50: 176-187. http://dx.doi.org/10.1002/mnfr.200500102

World Health Organization (WHO) (2008). 10 facts on obesity. Available at [http://www.who.int/features/factfiles/obesity/ facts/en/index 1.html].

Wu AH, Spicer D, Stanczyk FZ, Tseng CC, et al. (2012). Effect of 2-month controlled green tea intervention on lipoprotein cholesterol, glucose, and hormone levels in healthy postmenopausal women. Cancer Prev. Res. (Phila.) 5: 393-402. http://dx.doi.org/10.1158/1940-6207.CAPR-11-0407

Wu L and Parhofer KG (2014). Diabetic dyslipidemia. Metabolism 63: 1469-1479. http://dx.doi.org/10.1016/j. metabol.2014.08.010

Yoo SW, Savchev S, Sergott L, Rezai T, et al. (2011). A large network of interconnected signaling pathways in human ovarian follicles is supported by the gene expression activity of the granulosa cells. Reprod. Sci. 18: 476-484. http:// dx.doi.org/10.1177/1933719110388848

Zar JH (1999). Biostatistical analysis. Prentice Hall, New Jersey.

Genetics and Molecular Research 16 (2): gmr16029605 